\title{
Histoplasma capsulatum yeast phase-specific protein Yps3p induces Toll-like receptor 2 signaling
}

\author{
Rajagopal N Aravalli*1,3, Shuxian Hu${ }^{1}$, Jon P Woods ${ }^{2}$ and \\ James R Lokensgard ${ }^{1}$
}

Address: ${ }^{1}$ Center for Infectious Diseases and Microbiology Translational Research, University of Minnesota Medical School, Minneapolis, Minnesota, USA, ${ }^{2}$ Department of Medical Microbiology and Immunology, University of Wisconsin Medical School, Madison, Wisconsin, USA and ${ }^{3}$ Department of Radiology, Mayo MMC 292, University of Minnesota Medical School, 420 Delaware Street SE, Minneapolis, MN 55455, USA

Email: Rajagopal N Aravalli* - arava001@umn.edu; Shuxian Hu - huxxx001@umn.edu; Jon P Woods - jpwoods@wisc.edu; James R Lokensgard - loken006@umn.edu

* Corresponding author

Published: 7 July 2008

Journal of Neuroinflammation 2008, 5:30 doi:10.1/86/1742-2094-5-30
Received: 5 February 2008

Accepted: 7 July 2008

This article is available from: http://www.jneuroinflammation.com/content/5/I/30

(c) 2008 Aravalli et al; licensee BioMed Central Ltd.

This is an Open Access article distributed under the terms of the Creative Commons Attribution License (http://creativecommons.org/licenses/by/2.0), which permits unrestricted use, distribution, and reproduction in any medium, provided the original work is properly cited.

\begin{abstract}
Histoplasma capsulatum is a common cause of fungal infection in certain geographic areas, and although most infections are asymptomatic, it is capable of causing histoplasmosis, a disseminated, life-threatening disease, especially in immunocompromised individuals. A deeper understanding of this host-pathogen interaction is needed to develop novel therapeutic strategies to counter lethal infection. Although several lines of evidence suggest that this fungus is neurotropic in HIV patients, little is known about the immunobiology of Histoplasma infection in the central nervous system [CNS]. The goal of the present study was to understand the innate neuroimmune mechanisms that recognize $H$. capsulatum during the initial stages of infection. Using a 293T stable cell line expressing murine Toll-like receptor 2 [TLR2], we show here that TLR2 recognizes $H$. capsulatum cell wall protein Yps3p and induces the activation of NF- $\kappa B$. In further experiments, we tested the ability of Yps3p to induce signaling from TLR2 in primary microglial cells, the resident brain macrophages of the CNS. Our data show that $H$. capsulatum Yps3p induced TLR2 signaling in wild-type microglia, but not in microglia isolated from TLR2 KO mice, confirming that Yps3p is a ligand for TLR2. Furthermore, Yps3p-induced TLR2 signaling was suppressed by vaccinia virus-encoded TLR inhibitors. This is the first demonstration of a fungal protein serving as a TLR ligand and mediating signaling in primary brain cells.
\end{abstract}

\section{Background}

Inhalation of the human pathogenic fungus Histoplasma capsulatum may result in histoplasmosis, an important emerging infectious disease that occurs in immunocompromised individuals and transplant patients [1]. Among the known varieties of this opportunistic fungus, H. capsulatum var capsulatum [referred hereafter as H. capsulatum] is present mostly in North and Central America, whereas
H. capsulatum var. duboisii is endemic in Africa (reviewed in [2]). Histoplasmosis has also been reported to occur in the central nervous system [CNS] [1,3-5]. Current treatments for CNS histoplasmosis with amphotericin B combined with one of two commonly used azoles, fluoconazole and itraconazole, have not been encouraging $[2,6-8]$ although successful outcomes have been reported $[7,9,10]$. In some instances, histoplasmosis may 
manifest either as myelopathy or as brain tumor further complicating the diagnosis $[11,12]$. Treatment with fluconazole in the mouse model of intracranial infection has been proved to be ineffective [6]. Therefore, extensive efforts are being made to develop novel diagnostic tools and anti-fungal therapies to diagnose histoplasmosis and to curtail its progression.

H. capsulatum is a dimorphic fungus that exists as mycelium at $25^{\circ} \mathrm{C}$ and as yeast at $37^{\circ} \mathrm{C}$ [13]. Conversion of mycelium to the yeast phase has been demonstrated to be critical for pathogenicity of the fungus as agents that inhibit the dimorphic transition, such as p-chloromercuriphenylsulfonic acid, render virulent $H$. capsulatum strains avirulent [14]. Macrophages provide a protected environment for $H$. capsulatum to multiply and disseminate from the lungs to other organs. Initial studies with murine macrophages demonstrated that $H$. capsulatum could survive in the harsh conditions of phagolysosomal compartments [15] and modulate the $\mathrm{pH}$ of its intracellular niche [16]. This fungus was later shown to survive in 'modified' lysosomes in human macrophages, as well in the RAW264.7 cell line [17].

Toll-like receptors [TLRs] are a class of pathogen-recognition receptors that recognize specific molecular patterns [PAMPs] on the surface of invading pathogens and generate innate immune responses to counter infection [18]. Microglia have been shown to express mRNAs for all known TLRs [19], and recent reports demonstrate that TLR2 on microglial cells recognizes a number of PAMPs and triggers immune responses [20-22]. A critical role for TLRs in recognizing and triggering innate immune responses against several opportunistic fungal pathogens such as Candida albicans, Aspergillus fumigatus, and Cryptococcus neoformans have been reported [23-32]. In contrast to these organisms, little is known about the involvement of TLRs in host responses to dimorphic fungi such as $H$. capsulatum, Coccidiodes immitis, Blastomyces dermatitidis and Paracoccoidioides brasiliensis. To date, fungal cell wall and capsule components such as phospholipomannan and zymosan were reported to be ligands for a number of cellular receptors, including the TLRs, but specific fungal proteins that could induce signaling from these receptors have not yet been identified.

Several H. capsulatum genes have been found to be differentially expressed during phase transition, and one such gene YPS3 is induced within $2 \mathrm{~h}$ following the $25^{\circ} \mathrm{C}$-to$37^{\circ} \mathrm{C}$ temperature shift [13]. This yeast-phase-specific gene encodes the Yps3p protein that is localized to its cell wall and is also expressed as a secretory protein in infected cells $[33,34]$. It has been proposed that Yps3p may have a regulatory role in fungal transition and may correlate with pathogenicity [13]. Murine T cells recognize components from cell wall and cell membrane extracts of $H$. capsulatum [35], suggesting that fungal wall components are recognized by immune cells. In this study, we show for the first time that $H$. capsulatum cell membrane protein Yps3p triggers TLR2 signaling and leads to the activation of NF- $\mathrm{KB}$ in primary microglial cells.

\section{Methods \\ Organism and culture conditions}

H. capsulatum G217B [ATCC 26032] is a North American isolate of RFLP class 2 which was termed 'high level' in thermotolerance and pathogenicity. The fungus was grown in Histoplasma-macrophage medium (HMM) broth [36] in a $5 \% \mathrm{CO}_{2}-95 \%$ air atmosphere. Experiments were performed with $H$. capsulatum grown as yeast cells at $37^{\circ} \mathrm{C}$.

\section{Cloning, expression, and purification of recombinant fungal proteins}

Recombinant Yps3p and $\mathrm{H}$ proteins was prepared as described previously $[33,37]$. For the preparation of crude cell extract, fractionation was done as follows: log-phase yeast cells were pelleted by centrifugation, washed, and resuspended in PBS. They were then disrupted using glass beads in a Mini-Beadbeater-8 (Biospec Products, Bartlesville, $\mathrm{OK}$ ) at highest setting for three 1 min periods, separated by chilling on ice for $1 \mathrm{~min}$. Beads were removed by low-speed centrifugation and the cell lysate was spun at $15 \mathrm{~K} \mathrm{RPM}$ in a microcentrifuge at $4 \mathrm{C}$ for $30 \mathrm{~min}$. The supernatant was removed as the cytoplasmic fraction. The pellet was resuspended in PBS as the cell wall/membrane fraction.

\section{Preparation of microglial cultures}

Microglial cell cultures were purified from wild-type C57BL/6 and TLR2 KO mice (Jackson Laboratories, Bar Harbor, ME) using a method described previously with minor modifications [38]. Briefly, cerebral cortical cells from 1-d-old mice were dissociated after a $30 \mathrm{~min}$ trypsinization [0.25\%] and plated in $75-\mathrm{cm}^{2}$ Falcon culture flask in DMEM (Sigma-Aldrich, St. Louis, MO) containing 10\% heat-inactivated FBS (Hyclone Laboratories, Logan, UT)and penicillin/streptomycin (Sigma-Aldrich). The medium was replenished 1 and $4 \mathrm{~d}$ after plating. On $\mathrm{d} 8$ of culture, flasks were shaken for $20 \mathrm{~min}$ at a speed of $180 \mathrm{rpm}$ in an orbital shaker to remove unattached cells. On d 12 of culture, microglia floating in the media were collected by aspiration, pooled, centrifuged and seeded at appropriate densities after counting. The cells were washed twice with fresh medium $1 \mathrm{~h}$ after seeding to remove non-adherent cells. Microglia prepared this way stain $95-98 \%$ positive with Mac-1 antibody (Roche Applied Science, Indianapolis, IN). 


\section{Cloning of VV TLR inhibitors}

DNA obtained from the VV Western Reserve strain was used to clone four viral gene products: A46R, A52R, N1L and K1L using PCR. Primers used for amplification were: A46R: Forward: 5'-CAT GCC ATG GCG TTT GAT ATC AGT-3' and Reverse: 5'-CAT GCC ATG GAT GGC GTT TGA TAT-3'; A52R: Forward: 5'-CAT GCC ATG GAC ATA AAG ATA GAT-3' and Reverse: 5'-GTG GAA ATG TCA TAG GCT AGC TAG-3'; N1L: Forward: 5'-CAG GTC ATG AGG ACT CTA CTT ATT-3' and Reverse: 5'-CTA GCT AGC TTA TTT TTC ACC ATA-3'; K1L: Forward: 5'-CAG GAT ATC ATG GAT CTG TCA CGA-3' and Reverse: 5'-CTA GCT AGC TTA GTT TTT CTT TAC AC-3'. PCR was performed on a Gradient 40 Robocycler (Stratagene, La Jolla, CA) using Pfu polymerase (Stratagene) with the following conditions: initial denaturation at $95^{\circ} \mathrm{C}$ for $2 \mathrm{~min} 30 \mathrm{sec}$, followed by 30 cycles of $95^{\circ} \mathrm{C}$ for $1 \mathrm{~min}$, annealing at $60^{\circ} \mathrm{C}$ for $1 \mathrm{~min}$ and elongation at $72^{\circ} \mathrm{C}$ for $3 \mathrm{~min}$. Following PCR amplification, viral gene products were purified using a $0.8 \%$ agarose gel and were cloned into pORF5-mIL10 (InvivoGen) by replacing the mIL-10 ORF with each VV ORF as described previously [39]. This vector carries the murine IL-10 ORF under the control of a composite binary promoter comprised of the elongation factor $1 \alpha$ (EF-1 $\alpha)$ and the 5' untranslated region of the human eukaryotic initiation factor $4 \mathrm{~g}$ ( $\mathrm{eIF}-4 \mathrm{~g}$ ). The expression vectors thus generated were termed pORF5-A46R, pORF5-A52R, pORF5$\mathrm{N} 1 \mathrm{~L}$ and pORF5-K1L. Expression of these viral proteins was confirmed using Western blot analysis [39].

\section{Luciferase assay}

HEK293T cells, as well as wild-type and TLR2 KO microglia, were transfected with $1 \mu \mathrm{g}$ pNiFty2-Luc plasmid (InvivoGen) expressing an NF-кB-driven firefly luciferase reporter gene. FuGene 6 was used for transfection of the 293T-mTLR2 cells. Primary microglia are post-mitotic cells which are extremely difficult to transfect using standard methods. In this study, they were successfully transfected using the mouse macrophage nucleofection kit (Amaxa Biosystems, Gaithersburg, MD) and the program Y-01 on the nucleofector I device (Amaxa). Although the transfection efficiency using nucleofection was still low $(<10 \%)$, luciferase expression occured only in cells that took up the pNiFty2-Luc plasmid. Following nucleofection, the cells were plated in 12-well plates and incubated overnight at $37^{\circ} \mathrm{C}$. To stimulate TLR2 signaling, $0.01 \%$ heat-killed L. monocytogenes (InvivoGen) was added to the culture medium for $5 \mathrm{~h}$. The cells were then lysed and luciferase activity was measured using Bright-Glo luciferase assay substrate (Promega, Madison, WI) on the IVIS $^{\circledR}$ Imaging System (Xenogen Corporation, Alameda, CA). Expression levels of the luciferase reported gene were quantified using Living Image ${ }^{\circledast}$ software (Xenogen). Tranfection efficiencies were tested using a control plasmid expressing green fluorescent protein under the control of
CMV IE promoter and the values were normalized to the transfection efficiencies obtained.

\section{ELISA assay}

A sandwich ELISA-based system was used to quantify CCL2 levels from WT and TLR2 KO murine microglial cell culture supernatants. ELISA plates were coated with ratanti-mouse CCL2 capture antibodies (R\&D Systems, Minneapolis, $\mathrm{MN}$ ) at $1-2 \mu \mathrm{g} / \mathrm{ml}$ overnight at $4{ }^{\circ} \mathrm{C}$. The plates were washed $(0.05 \%$ Tween-20 in phosphate-buffered saline, PBS) and blocked with 1\% BSA in PBS for $1 \mathrm{~h}$ at $37^{\circ} \mathrm{C}$. Detection antibodies (biotinylated goat antimouse CCL2 antibodies, $1-2 \mu \mathrm{g} / \mathrm{ml}$; R\&D Systems) were added for $90 \mathrm{~min}$ at room temperature followed by peroxidase conjugated strepavidin (1:3000; Jackson Immunoresearch) for $45 \mathrm{~min}$. A chromogenic substrate (K-blue; Neogen Corporation, Lexington, KY) was then added and color development was stopped with $1 \mathrm{M} \mathrm{H}_{2} \mathrm{SO}_{4}$. Absorbance values at $450 \mathrm{~nm}$ were used to quantify chemokine levels based on the standard concentration curve generated from serial dilutions.

\section{Results \\ Histoplasma capsulatum protein $Y p s 3 p$ is a ligand for Toll-like receptor 2}

TLRs recognize PAMPs on the surface of pathogens and activate the host's innate immune responses. A number of fungal cell wall components such as mannan, phospholipomannan, and zymosan have previously been shown to be recognized by TLR2 and TLR4 $[18,19,29,40]$. In order to determine which component of the H. capsulatum cell wall/membrane activated the TLR2 signaling pathway, we have used a stable cell line that expresses murine TLR2 under the control of a composite promoter comprised of the eukaryotic elongation factor- $1 \alpha$ (EF-1 $\alpha)$ core promoter and the $\mathrm{R}$ segment, as well as part of the U5 sequence, of the human T-cell leukemia virus type 1 long terminal repeat [39]. These 293T-mTLR2 cells were transfected with the plasmid pNiFty2-Luc, containing the open-reading frame for luciferase under the regulation of five NF- $\kappa \mathrm{B}$ binding sites. Using this experimental design, signaling from TLR2 results in the activation of $N F-\kappa B$ which, in turn, activates luciferase expression. Thus, luciferase expression does not occur in the absence of TLR2 signaling. (Fig. 1).

The fungal cell wall fraction was isolated and used to treat 293-mTLR2 cells. Two other fungal proteins Yps3p and H, purified following expression in E. coli, were also tested. $\mathrm{H}$ protein serves as a negative control and heat-killed Listeria monocytogenes, a strong inducer of TLR2 signaling, was used as a positive control. As shown in Fig. 2, neither the cell wall fraction (CW) nor the recombinant $\mathrm{H}$ protein activated signaling through TLR2. There was no significant luciferase production above the background levels in 


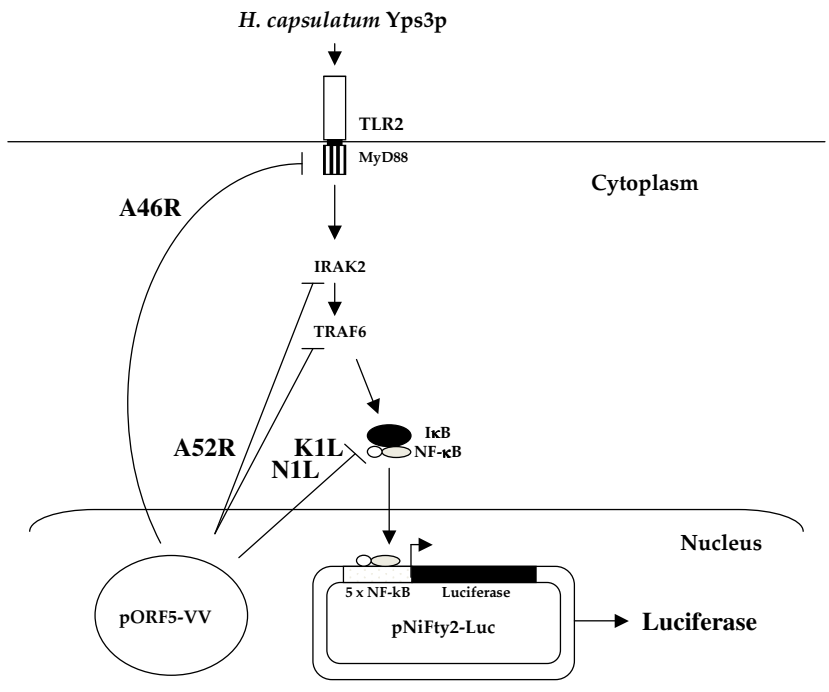

Figure I

Experimental design. Induction of TLR signaling by $H$. capsulatum Yps3p protein leads to the activation of IRAK2 and NF$\kappa B$. NF- $\kappa B$ is then released from its inhibitor $I \kappa B$ and translocates into the nucleus, where it binds to one of five NF- $\kappa B$ binding sites on the pNiFty2-Luc plasmid, and subsequently activates transcription to produce luciferase. Vaccinia virus [VV] protein A46R targets multiple TLR adaptors including MyD88, and A52R associates with IRAK-I and TRAF6 to disrupt downstream signaling. VV NIL and KIL proteins prevent the release of NF- $\kappa B$ from $I \kappa B$. Expression of these proteins from their corresponding pORF5-VV plasmid leads to the inhibition of NF- $\kappa \mathrm{B}$ activation and decreased luciferase expression from pNiFty2-Luc.

these samples. On the other hand, the recombinant protein Yps3p induced TLR2 activation that resulted in a marked increase in luciferase production, demonstrating that Yps3p protein is a ligand for TLR2.

\section{Vaccinia virus proteins inhibitors of TLR signaling blunt Yps3p-induced luciferase expression}

To further confirm the role of TLR2 in responding to $H$. capsulatum, we next attempted to inhibit this signaling pathway using four vaccinia virus([VV) proteins. Among these viral proteins, A46R inhibits signaling from MyD88, the cytoplasmic adaptor of TLR2 [41], and A52R interacts with and blocks the activity of two downstream molecules IRAK2 and TRAF6 along the TLR2 pathway $[41,42]$; whereas $\mathrm{N} 1 \mathrm{~L}$ and $\mathrm{K} 1 \mathrm{~L}$ prevent the release of NF- $\mathrm{KB}$ from its inhibitor $\mathrm{I} \kappa \mathrm{B} \alpha[43,44]$ (Fig. 1). ORFs of each of these $\mathrm{VV}$ proteins were cloned into the pORF5 vector under the control of a composite binary promoter comprised of the elongation factor $1 \alpha(\mathrm{EF}-1 \alpha)$ and the eukaryotic initiation factor $4 \mathrm{~g}$ (eIF-4g). $1 \mu \mathrm{g}$ of each pORF5-VV plasmid was cotransfected into 293T-mTLR2 cells together with $1 \mu \mathrm{g}$ of pNiFty2-Luc. Following overnight incubation at $37^{\circ} \mathrm{C}$,

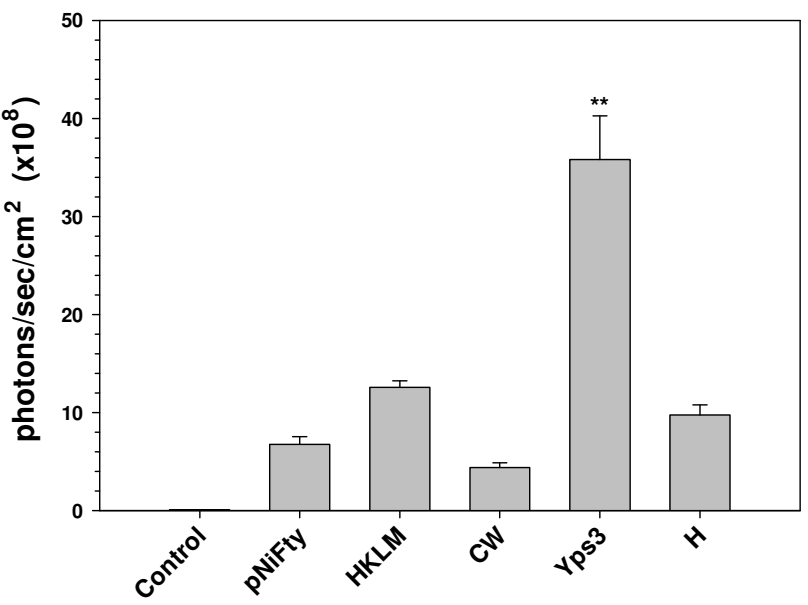

Figure 2

Identification of Yps3p as a TLR2 ligand in 293T cells. pNiFty2-Luc transfected 293T-mTLR2 cells were treated with $H$. capsulatum cell wall/membrane fraction [CW], recombinant Yps3p [Yps3p], and recombinant protein $\mathrm{H}[\mathrm{H}]$. Untreated cells were used as a control for background luciferase expression [pNIFty] and heat-killed Listeria monocytogenes [HKLM] was added to cells as a positive control for TLR2 signaling. Data are presented as mean \pm SD of triplicate samples and are representative of three independent experiments. Statistical analysis was performed by student's $t$ test. $* P<0.05 ; * * p<0.01$.

the cells were treated with Yps3p for $6 \mathrm{~h}$, harvested and the expression levels of luciferase in the transfected cells were measured using a luciferase assay. The data show that $\mathrm{NF}-\kappa \mathrm{B}$ activation was severely impaired in cells expressing each of these viral proteins when compared to cells expressing pNiFty2-Luc alone, a result which demonstrates that all four viral proteins were able to inhibit Yps3p-induced TLR2 signaling in 293T-mTLR2 cells (Fig. 3 ). This result not only confirmed Yps3p mediation of TLR2 signaling but also showed that it can be inhibited at different levels (at the receptor as well as downstream) along the TLR2 signaling pathway.

\section{TLR2 is required for $Y p s 3 p$-induced activation of NF- $\kappa B$ in primary murine microglia}

Having determined that $H$. capsulatum protein Yps3p engages TLR2 signaling pathway and causes NF- $\kappa$ B activation in our 293T-mTLR2 cell line, we went on to determine whether Yps3p protein also induced NF-kB activation in primary brain cells. For this experiment, microglial cells from wild-type $\mathrm{C} 57 \mathrm{BL} / 6$ mice as well as TLR2 KO mice were isolated and transfected with pNiFty2-Luc plasmid using nucleofection. After overnight incubation at $37^{\circ} \mathrm{C}$, the microglia were exposed to the recombinant fungal protein for $6 \mathrm{~h}$. The cells were then harvested and a luciferase assay was performed. In these 


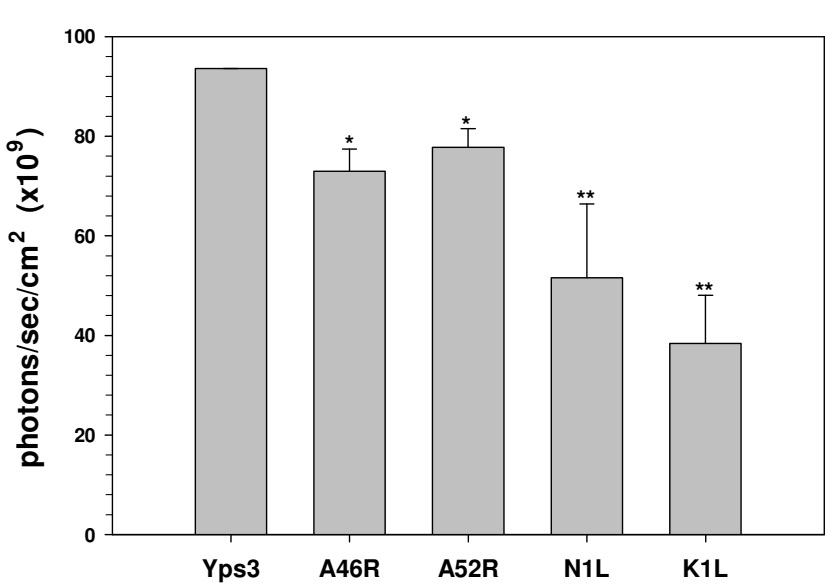

Figure 3

Inhibition of TLR2-mediated, Yps3p-induced NF- $\kappa$ B activation in 293T-mTLR2 cells by VV proteins. Plasmids carrying the open-reading frames of $A 46 R, A 52 R, K I L$, or NIL were co-transfected along with pNiFty2-Luc, cells were incubated overnight at $37^{\circ} \mathrm{C}$ and treated with Yps3p for $5 \mathrm{~h}$. Cells were then harvested and the amount of luciferase produced was quantified using bright glow substrate. Data are presented as mean $\pm S D$ of triplicate samples and are representative of three independent experiments. Statistical analysis was performed by student's $t$ test. $* p<0.05$; $* * p<0.01$.

experiments, Yps3p-induced TLR2 signaling in wild-type microglial cells resulted in high levels of luciferase expression, demonstrating an increased level of NF- $\kappa \mathrm{B}$ activation (Fig. 4). In contrast, a significant reduction in luciferase expression occurred following the identical treatment using TLR2 KO microglia. This result further demonstrates that Yps3p triggered signaling through TLR2.

To further test the role of Yps3p in triggering TLR2 signaling, we performed an ELISA for the proinflammatory immune mediator Chemokine (C-C motif) ligand 2 (CCL2) in wild-type and TLR2 KO microglial cells. The amount to CCL2 secreted into the culture supernatants of microglial cells was quantified using an ELISA assay. While there was no difference in the expression of CCL2 between untreated samples, the expression of CCL2 was elevated in the both wild-type and TLR2 KO microglia following the treatment with Yps3p (Fig. 5). However, the expression levels obtained for TLR2KO microglia were significantly lower than those obtained for wild-type microglia, suggesting that the activation of TLR2 by Yps3p results in the production of CCL2 in these cells.

\section{Discussion}

Airborne invasive fungal pathogens can cause morbidity and mortality in immunocompromised individuals,

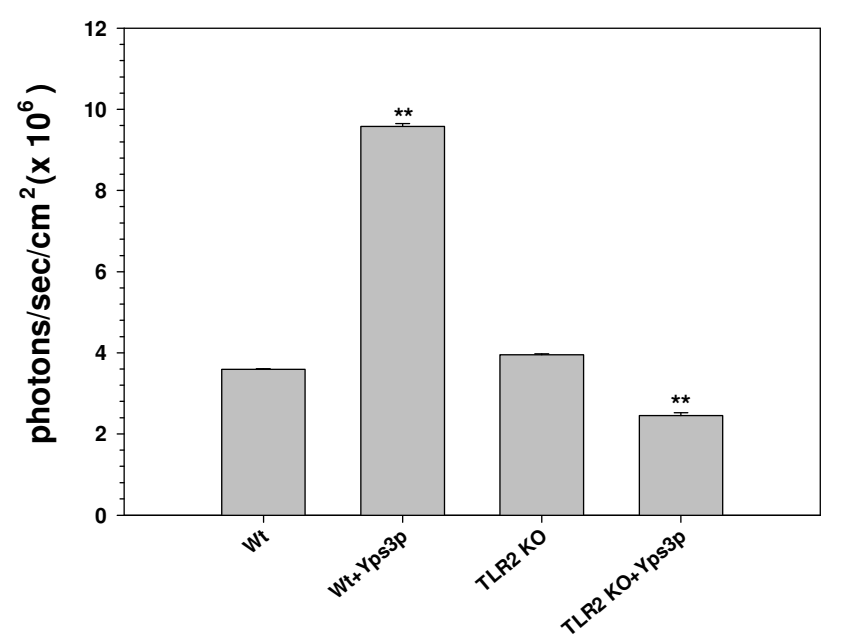

\section{Figure 4}

Activation of NF- $\mathrm{KB}$ in primary murine microglia following treatment with Yps3p. Purified microglial cells $\left[1 \times 10^{6}\right]$ from wild-type and TLR2 knockout mice were transiently transfected with pNiFty2-Luc plasmid by electroporation using the mouse macrophage nucleofector kit. The cells were incubated overnight at $37^{\circ} \mathrm{C}$ and $1.5 \mu \mathrm{g}$ Yps $3 p$ was added to the cell culture medium. The microglia were harvested after $5 \mathrm{~h}$ and the amount of luciferase produced as a result of NF-KB activation was quantified using the bright glow substrate. Data are presented as mean \pm SD of triplicate samples and are representative of three independent experiments. Statistical analysis was performed by student's $t$ test. ${ }^{* * P}<0.01$.

including those with HIV/AIDS. H. capsulatum is a major cause of respiratory infections worldwide and is the etiologic agent of histoplasmosis. In addition to respiratory infections, histoplasmosis has been reported to occur in the brain [1,3-5]. In the present study, we showed that the interaction of $H$. capsulatum Yps3p with microglial cells leads to NF-kB activation via the TLR2 pathway, in both a stable cell line expressing murine TLR2 as well as in primary microglia.

Studies aimed at understanding the role of TLRs in fungal recognition have been controversial. While TLR2 has been shown to be essential for immune responses in macrophages [28], TLR2 KO mice were found to be resistant to candidiasis. It has been reported that both TLR2 and TLR4 are key cellular receptors that recognize opportunistic fungal pathogens such as C. albicans, A. fumigatus and C. neoformans. Phosholipomannan, a unique glycoprotein in the cell wall of C. albicans, is a ligand of TLR2, and when mouse macrophages are infected with C. albicans they activate NF- $\kappa B$ and produce TNF- $\alpha$. $[28,40]$. While TLR2 has been shown to be essential for defense against $C$. albicans [38], contrasting results were reported with TLR2 KO mice being resistant to candidiasis whereas TLR4 KO mice were 


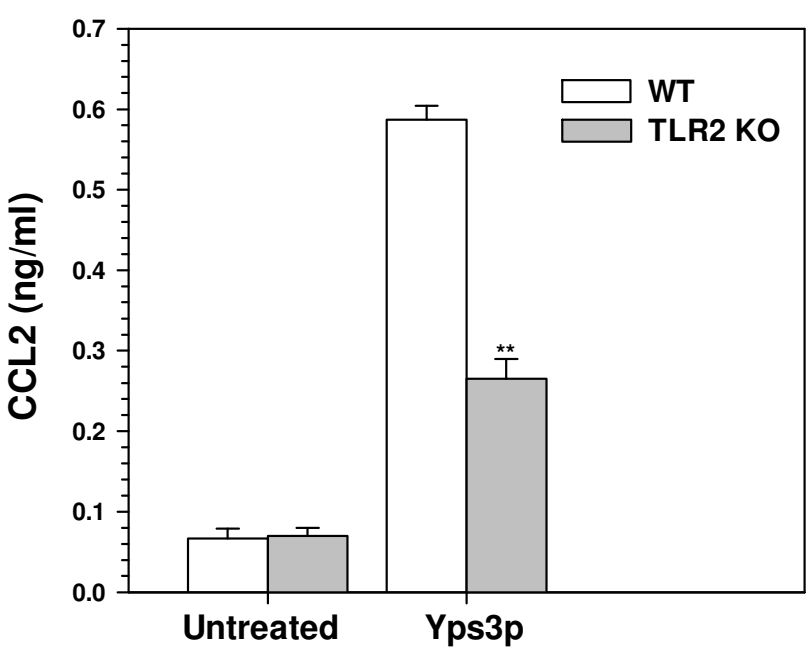

Figure 5

TLR2-mediated expression of CCL2 in response to Yps3p. ELISA assay was performed with purified microglial cells from wild-type and TLR2 knockout mice following exposure with $3 \mu \mathrm{g} / \mathrm{ml}$ Yps3p. Data are presented as relative induction of CCL2 and bars represent the mean \pm SD of triplicate samples, which are representative of at least three independent experiments. Statistical analysis was performed by student's $t$ test. $* * p<0.01$.

susceptible [26,27]. Both in vitro experiments using macrophages and transfected cell lines, as well as in vivo experiments with experiments using TLR-deficient mice infected with A. fumigatus, have suggested a role for TLR2 and TLR4 $[23,25,31,45]$. Similarly, one study showed that TLR2 signaling was necessary for host defense against $C$. neoformans [24], while another reported limited involvement of TLR2 and TLR4 in response to C. neoformans infection [32].

\section{Conclusion}

In this study, we report for the first time that $H$. capsulatum triggers TLR2 signaling leading to NF- $\mathrm{B}$ activation in microglial cells and that Yps3p protein is an important fungal component that induces TLR2 signaling. A deeper understanding of host-pathogen interactions will enable us to tackle new challenges posed by fungal pathogens and develop improved therapeutic measures to treat histoplasmosis as well as other deadly mycological diseases.

\section{Competing interests}

The authors declare that they have no competing interests.

\section{Authors' contributions}

RNA and JRL conceived the study. RNA and SH performed experiments. JPW provided $H$. capsulatum materials. RNA and JRL analyzed the data. RNA designed the study and drafted the manuscript. All authors have read and approved the final manuscript.

\section{Acknowledgements}

This research was supported in part by a grant from the Minnesota Medical Foundation. JPW received support from NIH ROI awards HL055949 and Al052303. We thank Megan Bohse and Kimber Munson for recombinant protein purification, and Prof. Phillip Peterson for his input.

\section{References}

I. Anaissie E, Fainstein V, Samo T, Bodey GP, Sarosi GA: Central nervous system histoplasmosis. An unappreciated complication of the acquired immunodeficiency syndrome. Am J Med 1988, 84:215-217.

2. Kauffman CA: Histoplasmosis: a clinical and laboratory update. Clin Microbiol Rev 2007, 20: I I5-I 32.

3. Tan V, Wilkins P, Badve S, Coppen M, Lucas S, Hay R, Schon F: Histoplasmosis of the central nervous system. I Neurol Neurosurg Psychiatry 1992, 55:619-622.

4. Vos MJ, Debets-Ossenkopp YJ, Claessen FA, Hazenberg GJ, Heimans JJ: Cerebellar and medullar histoplasmosis. Neurology 2000, 54:144I.

5. Walsh TJ, Groll AH: Emerging fungal pathogens: evolving challenges to immunocompromised patients for the twenty-first century. Transpl Infect Dis 1999, I:247-26I.

6. Haynes RR, Connolly PA, Durkin MM, LeMonte AM, Smedema ML, Brizendine $E$, Wheat $L J$ : Antifungal therapy for central nervous system histoplasmosis, using a newly developed intracranial model of infection. J Infect Dis 2002, I 85: 1830-1832.

7. LeMonte AM, Washum KE, Smedema ML, Schnizlein-Bick C, Kohler SM, Wheat LJ: Amphotericin B combined with itraconazole or fluconazole for treatment of histoplasmosis. J Infect Dis 2000, 182:545-550.

8. Wheat J, Hafner R, Korzun AH, Limjoco MT, Spencer P, Larsen RA, Hecht GFM, Powderly W, AIDS Clinical Trial Group: Itraconazole treatment of disseminated histoplasmosis in patients with the acquired immunodeficiency syndrome. Am J Med 1995, 98:336-342.

9. Knapp S, Turnherr M, Dekan G, Willinger B, Stingl G, Rieger A: A case of HIV-associated cerebral histoplasmosis successfully treated with fluconazole. Eur J Clin Microbiol Infect Dis 1999, | 8:658-661.

10. Tiraboschi I, Cases Parera I, Pikielny R, Scattini G, Michell F: Chronic Histoplasma capsulatum infection of the central nervous system successfully treated with fluconazole. Eur Neurol 1992, 32:70-73.

II. Klein C], Dinapoli RP, Temesgen Z, Meyer FB: Central nervous system histoplasmosis mimicking a brain tumor: difficulties in diagnosis and treatment. Mayo Clin Proc 1999, 74:803-807.

12. Voelker JL, Muller J, Worth RM: Intermedullary spinal Histoplasma granuloma: case report. J Neurosurg 1989, 70:959-96I.

13. Keath EJ, Painter AA, Kobayashi GS, Medoff G: Variable expression of a yeast-phase-specific gene in Histoplasma capsulatum strains differing in thermotolerance and virulence. Infect Immun 1989, 57:1384-1390.

14. Medoff G, Sacco M, Maresca B, Schlessinger D, Painter A, Kobayashi GS, Carratu L: Irreversible block of the mycelial-to-yeast phase transition of Histoplasma capsulatum. Science 1986, $231: 476-479$.

15. Eissenberg LG, Goldman WE, Schlesinger PH: Histoplasma capsulatum modulates the acidification of phagolysosomes. J Exp Med 1993, 177:1605-161I.

16. Eissenberg LG, Schlesinger PH, Goldman WE: Phagosome-lysosome fusion in P388DI macrophages infected with Histoplasma capsulatum. J Leukoc Biol 1988, 43:483-49I.

17. Strasser JE, Newman SL, Ciraolo GM, Morris RE, Howell ML, Dean GE: Regulation of the macrophage vacuolar ATPase and phagosome-lysosome fusion by Histoplasma capsulatum. J Immunol 1999, 162:6148-6154

18. Akira S, Uematsu S, Takeuchi O: Pathogen recognition and innate immunity. Cell 2006, 124:783-80I. 
19. Aravalli RN, Peterson PK, Lokensgard JR: Toll-like receptors in defense and damage of the central nervous system. J Neuroimmune Pharmacol 2007, 2:291-302.

20. Aravalli RN, Hu S, Rowen TN, Palmquist J, Lokensgard JR: Cutting Edge: TLR2-mediated production of proinflammatory cytokines and chemokines by microglial cells in response to herpes simplex virus. J Immunol 2005, I 75:4I89-4I73.

21. Kielian T, Esen N, Bearden ED: Toll-like receptor 2 (TLR2) is pivotal for recognition of $S$. aureus peptidoglycan but not intact bacteria by microglia. Glia 2005, 49:567-576.

22. Kinsner A, Boveri M, Hareng L, Brown GC, Coecke S, Hartung T, BalPrice A: Highly purified lipoteichoic acid induced pro-inflammatory signalling in primary culture of rat microglia through Toll-like receptor 2: selective potentiation of nitric oxide production by muramyl dipeptide. I Neurochem 2006, 99:596-607.

23. Bellocchio S, Montagnoli C, Bozza S, Gaziano R, Rossi G, Mambula SS, Vecchi A, Mantovani A, Levitz SM, Romani L: The contribution of the Toll-like/IL-I receptor superfamily to innate and adaptive immunity to fungal pathogens in vivo. J Immunol 2004, I 72:3059-3069.

24. Biondo C, Midiri A, Messina L, Tomasello F, Garufi G, Catania MR, Bombaci M, Beninati C, Teti G, Mancuso G: MyD88 and TLR2, but not TLR4, are required for host defense against Cryptococcus neoformans. Eur J Immunol 2005, 35:870-878.

25. Mambula SS, Sau K, Henneke P, Golenbock DT, Levitz SM: Toll-like receptor [TLR] signaling in response to Aspergillus fumigatus. J Biol Chem 2002, 277:39320-39326.

26. Netea MG, Sutmuller R, Hermann C, Graaf CA Van der, Meer JW Van der, van Krieken JH, Hartung T, Adema G, Kullberg BJ: Toll-like receptor 2 suppresses immunity against Candida albicans through induction of IL- 10 and regulatory $T$ cells. I Immunol 2004, I72:37|2-37/8.

27. Netea MG, Graaf CA Van Der, Vonk AG, Verschueren I, Meer JW Van Der, Kullberg BJ: The role of toll-like receptor [TLR] 2 and TLR4 in the host defense against disseminated candidiasis. J Infect Dis 2002, I85: | 483-1489.

28. Roeder A, Kirschning CJ, Schaller M, Weindl G, Wagner H, Korting HC, Rupec RA: Induction of nuclear factor-kappaB and c-Jun/ activator protein-I via toll-like receptor $\mathbf{2}$ in macrophages by antimycotic-treated Candida albicans. J Infect Dis 2004, 190:1318-1326.

29. Tada H, Nemoto E, Shimauchi H, Watanabe T, Mikami T, Matsumoto T, Ohno N, Tamura H, Shibata K, Akashi S, Miyake K, Sugawara S, Takada H: Saccharomyces cerevisiae - and Candida albicansderived mannan induced production of tumor necrosis factor alpha by human monocytes in a CDI4- and Toll-like receptor 4-dependent manner. Microbiol Immunol 2002, 46:503-5I2.

30. Villamon E, Gozalbo D, Roig P, O'Connor JE, Fradelizi D, Gil ML: Toll-like receptor-2 is essential in murine defenses against Candida albicans infections. Microbes Infect 2004, 6: I-7.

31. Balloy V, Si-Tahar M, Takeuchi O, Philippe B, Nahori MA, Tanguy M, Huerre M, Akira S, Latge JP, Chignard M: Involvement of toll-like receptor 2 in experimental invasive pulmonary aspergillosis. Infect Immun 2005, 73:5420-5425.

32. Nakamura K, Miyagi K, Koguchi Y, Kinjo Y, Uezu K, Kinjo T, Akamine M, Fujita J, Kawamura I, Mitsuyama M, Adachi Y, Ohno N, Takeda K, Akira S, Miyazato A, Kaku M, Kawakami K: Limited contribution of Toll-like receptor 2 and 4 to the host response to a fungal infectious pathogen, Cryptococcus neoformans. FEMS Immunol Med Microbiol 2006, 47: |48-I54.

33. Bohse ML, Woods JP: Surface localization of the Yps3p protein of Histoplasma capsulatum. Eukaryot Cell 2005, 4:685-693.

34. Weaver CH, Sheehan KC, Keath EJ: Localization of a yeastphase-specific gene product to the cell wall in Histoplasma capsulatum. Infect Immun 1996, 64:3048-3054.

35. Henderson HM, Deepe GS Jr: Recognition of Histoplasma capsulatum yeast-cell antigens by human lymphocytes and human T-cell clones. J Leukoc Biol 1992, 5 I:432-436.

36. Woods JP, Heinecke EL, Goldman WE: Electrotransformation and expression of bacterial genes encoding hygromycin phosphotransferase and beta-galactosidase in the pathogenic fungus Histoplasma capsulatum. Infect Immun 1998, 66:1697-1707.
37. Fisher KL, Woods JP: Determination of $\beta$-glucosidase enzymatic function of the Histoplasma capsulatum $\mathrm{H}$ antigen using a native expression system. Gene 2000, 247:191-197.

38. Chao CC, Molitor TW, Hu S: Neuroprotective role of IL-4 against activated microglia. J Immunol 1993, I 5 I: |473- |48I.

39. Aravalli RN, Hu S, Lokensgard JR: Inhibition of Toll-like receptor signaling in primary murine microglia. J Neuroimmune Pharmacol 2008, 3:5-II.

40. Jouault T, Ibata-Ombetta S, Takeuchi O, Trinel PA, Sacchetti P, Lefebvre $\mathrm{P}$, Akira S, Poulain D: Candida albicans phospholipomannan is sensed through toll-like receptors. J Infect Dis 2003, 188: $165-172$

4I. Bowie A, Kiss-Toth E, Symons JA, Smith GL, Dower SK, O'Neill LA: $A 46 R$ and $A 52 R$ from vaccinia virus are antagonists of host IL-I and toll-like receptor signaling. Proc Natl Acad Sci USA 2000, 97:10162-10167.

42. Harte MT, Haga IR, Maloney G, Gray P, Reading PC, Bartlett NW, Smith GL, Bowie A, O'Neill LA: The poxvirus protein A52R targets Toll-like receptor signaling complexes to suppress host defense. J Exp Med 2003, I97:343-35I.

43. DiPerna G, Stack J, Bowie AG, Boyd A, Kotwal G, Zhang Z, Arvikar S, Latz E, Fitzgerald KA, Marshall WL: Poxvirus protein NIL targets the I-kappaB kinase complex, inhibits signaling to NFkappaB by the tumor necrosis factor superfamily of receptors, and inhibits NF-kappaB and IRF3 signaling by toll-like receptors. J Biol Chem 2004, 279:36570-36578.

44. Shisler JL, Jin XL: The vaccinia virus $K I L$ gene product inhibits host NF- $\kappa B$ activation by preventing $I \kappa B \alpha$ degradation. J Virol 2004, 78:3553-3560.

45. Meier A, Kirschning CJ, Nikolaus T, Wagner H, Heesemann J, Ebel F: Toll-like receptor (TLR) 2 and TLR4 are essential for Aspergillus-induced activation of murine macrophages. Cell Microbiol 2003, 5:56I-570.

Publish with Bio Med Central and every scientist can read your work free of charge

"BioMed Central will be the most significant development for disseminating the results of biomedical research in our lifetime. "

Sir Paul Nurse, Cancer Research UK

Your research papers will be:

- available free of charge to the entire biomedical community

- peer reviewed and published immediately upon acceptance

- cited in PubMed and archived on PubMed Central

- yours - you keep the copyright
BiolMedcentral 